\title{
A biological tube technique for the repair of peripheral nerve defects using 'stuffed nerves'
}

\author{
Sercan Çapkın, M.D., ${ }^{1}$ Mustafa Akhisaroğlu, M.D., ${ }^{2}$ Bekir Uğur Ergür, M.D., ${ }^{3}$ \\ Ali Abdülkadir Bacakoğlu, M.D. ${ }^{4}$
}

\begin{abstract}
${ }^{1}$ Department of Orthopaedics and Traumatology, Hinis Şehit Yavuz Yürekseven State Hospital, Erzurum-Turkey 2Department of Physiology, Dokuz Eylül University Faculty of Medicine, İzmir-Turkey ${ }^{3}$ Department of Histology and Embryology, Dokuz Eylül University Faculty of Medicine, İzmir-Turkey ${ }^{4}$ Department of Orthopaedics and Traumatology, Dokuz Eylül University Faculty of Medicine, İzmir-Turkey
\end{abstract}

\section{ABSTRACT}

BACKGROUND: Presently described is research examining the "stuffed nerve" technique to repair peripheral nerve defects.

METHODS: Twenty-one male Wistar Albino rats were divided into 3 groups of 7, and standard 10-mm defects were created in the sciatic nerve of all subjects. Rats were treated with autogenous nerve graft (Group I), hollow vein graft (Group 2), or vein graft stuffed with shredded nerves (Group 3). After 12 weeks, electrophysiological and histomorphological analyses were performed to evaluate axonal regeneration.

RESULTS: Rat groups were compared in terms of latency period and peak-to-peak potential. Latency period was significantly shorter and peak-to-peak potential was significantly greater in Group I than in Group 2. However, latency period and peak-to-peak potential did not differ significantly between Groups I and 3 or between Groups 2 and 3. To evaluate axonal regeneration, number of axons, axon diameter and myelin sheath thickness was compared between groups. Results indicated that axonal regeneration was similar in Groups I and 3, and was better than results seen in Group 2.

CONCLUSION: The stuffed nerve technique is an alternative to autogenous nerve grafting and produces similar electrophysiological and histomorphological properties.

Keywords: Biological tube; peripheral nerve defect; stuffed nerve; vein graft.

\section{INTRODUCTION}

Early primary repair of peripheral nerve injuries can produce ideal reconstruction and provide good long-term functional outcomes. ${ }^{[1]}$ However, associated techniques can only be used to repair small defects without tension, thus limiting their application. ${ }^{[2]}$ In large defects where primary repair is not possible, standard treatment involves repair using autogenous nerves and microsurgical techniques. ${ }^{[2,3]}$ Autogenous nerve grafts can lead to donor site morbidity. ${ }^{[2,4-6]}$ Use of this

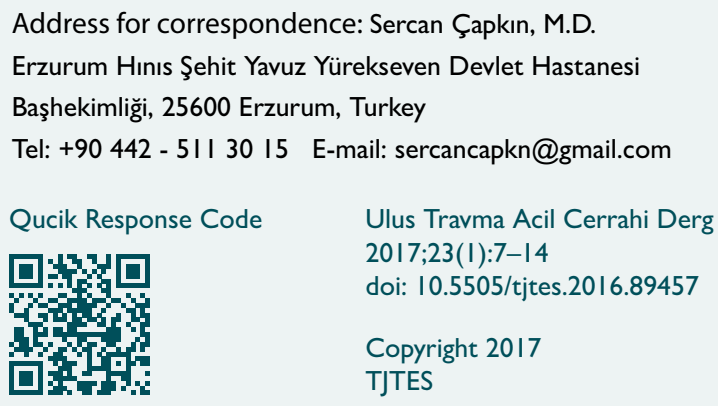

method is limited by disadvantages such as scar formation, multiple surgical requirements, loss of function, neuroma formation, graft harvesting difficulty, increased risk of secondary deformities due to extent of disease, tissue structure and size differences, as well as development of cold intolerance at distal end of the limb. ${ }^{[7,8]}$ Therefore, various conduits have been used to bridge peripheral nerve defects. ${ }^{[9-11]}$

Autogenous vein grafts are experimentally and clinically validated supportive tunnels for the regeneration and maturation of nerve fibers. ${ }^{[12,13]}$ Depending on capacity to regenerate nerve endings, nerve sprouts with axonal migration provide skeletal structure that contains extracellular matrix components and can be used with various growth factor supplements when necessary. Thus, vein grafts have most of the required qualities for neural tube models. ${ }^{[13]}$ However, the most frequently observed disadvantage of vein grafts is curling, which increases risk of collapse and fibrotic contraction. ${ }^{[14-16]}$ Most successful vein graft repairs are observed in defects less than $3 \mathrm{~cm}$ in length. ${ }^{[14]}$ Previous studies have demonstrated utility of filling inside of vein graft with nerve ${ }^{[17]}$ or muscle 
tissue $^{[18,19]}$ to prevent graft collapse, and this combined technique is effective for defects of less than $3 \mathrm{~cm}$.

In the present study, a biological tube was constructed and filled with nerve particles (stuffed nerve). It demonstrated superior peripheral nerve repair to that seen following routine autogenous nerve graft. The stuffed nerve technique utilizes microenvironment of vein graft and neurotropic factors from stuffed nerve particles.

\section{MATERIALS AND METHODS}

This study was approved by the animal ethics committee of Dokuz Eylül University. Twenty-one male Wistar Albino rats weighing approximately $300 \mathrm{~g}$ each were randomly divided into 3 equal groups. Surgery was performed on the lower extremities of right side in test animals and on left side in control animals. Rats were housed in cages (7 rats per cage) with water and rat chow ad libitum at room temperature with 12-hour light/ I2-hour dark cycle. Nerve graft, vein graft, and stuffed nerve technique was performed on 7 rats of Groups I, 2, and 3 , respectively.

\section{Surgical Procedures}

All surgical procedures were performed by the same investigator using microsurgical techniques in sterile conditions with a surgical microscope (Zeiss S3; Carl Zeiss AG, Oberkochen, Germany). Anesthesia of $10 \mathrm{mg} / \mathrm{kg}$ xylazine ( $2 \%$ alfazine, 20 $\mathrm{mg} / \mathrm{mL}$, Rompun; Bayer AG, Leverkusen, Germany; Bayer) and 100 mg/kg ketamine (Ketalar, 50 mg/mL; Pfizer, Inc., NY, NY, USA) was administered intraperitoneally. Oblique skin incision of approximately $3 \mathrm{~cm}$ in length was made from the right gluteal region to the posterior thigh in all test subjects, and sciatic nerve was exposed with blunt dissection of the superficial glu- teal and biceps femoris muscles and surrounding fascia junction line. From the sciatic foramen to point left of the tibial and common peroneal branches, sciatic nerve was separated and isolated from surrounding tissues (Fig. Ia). Seven $\mathrm{mm}$ of sciatic nerve from the proximal sciatic foramen to the point of separation from tibial and common peroneal branches was protected. Ten-mm sections from elsewhere on sciatic nerve were removed with microscissors. All anastomoses were performed using 10/0 ETHILON sutures (Ethicon, Inc., Somerville, NJ, USA). Nerve and vein grafting was performed using epineurial technique with 6 stitches for every $60^{\circ}$ angle.

Group I: In nerve graft group, standard 10-mm nerve defects were created in the subjects and excised $10-\mathrm{mm}$ segment was reversed and reapplied to the same site.

Group 2: Animals of the vein graft group received $10-\mathrm{mm}$ defect in sciatic nerve and vein graft from jugularis externa was used to repair defect.

Group 3: To prepare stuffed nerves, jugular vein graft of $\mathrm{I} \mathrm{cm}$ in length was harvested from left side of the cervical region and rinsed with saline solution (Fig. Ib). Sciatic nerve graft was cut into at least 10 parts of $1 \mathrm{~cm}$ each using microscissors (Fig. Ic). Initially, one end of vein graft was attached to proximal end of sciatic nerve using 10/0 ETHILON sutures (Fig. Id) and minced nerve graft was then equally distributed in the lumen of vein graft (Fig. le). Free end of vein graft was joined to distal end of sciatic nerve with 10/0 ETHILON sutures (Fig. If). All muscle and skin incisions were sutured using 4/0 absorbable sutures (Dogsan Tibbi Malzeme San A.S., Trabzon, Turkey). All rats were observed for 12 weeks in standard cages under the conditions described earlier and then underwent further surgery
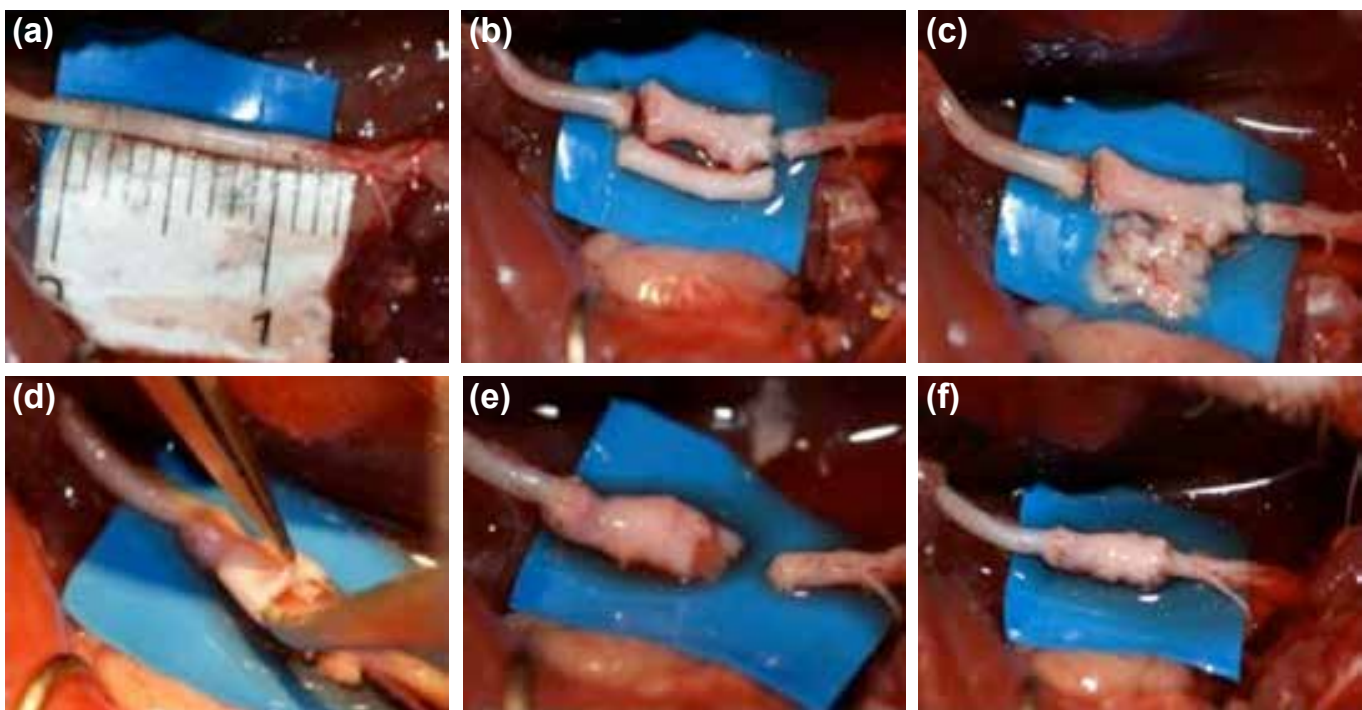

Figure 1. Preparation of a stuffed nerve. (a) exposure of the sciatic nerve, (b) replacement of 10-mm section from the sciatic nerve with vein graft, (c) rendering of excised nerve section, (d) proximal coaptation of vein graft and stuffing of the nerve particles from the distal end, (e) appearance of the nerve-stuffed vein graft segment, and (f) appearance of the nerve-stuffed vein graft after distal coaptation. 
to visualize the nerves. Electrophysiological function was determined using electroneuromyography (ENMG), and histological analyses were performed using light and electron microscopy after sacrifice.

\section{Electrophysiological Examination}

To evaluate regeneration of sciatic nerve, impulses were sent from proximal end of the nerve, and electrophysiological response of gastrocnemius muscle was recorded using ENMG. Stimuli were applied directly to the nerve for 0.1 milliseconds to avoid nonselective stimulation. Both control and treated sciatic nerves were dissected from the sciatic notch to the sciatic trifurcation using the previous incision, and impulse electrodes were positioned approximately $5-\mathrm{mm}$ proximal to coaptation area of the exposed sciatic nerve, and recording electrodes were positioned on the insertion and on middle part of the gastrocnemius muscle after passing through the skin. Impulse intensity that provided maximum muscle response was determined for each animal using gradual increase from minimum stimulus amplitude of $0.3 \mathrm{~V}$. Impulses were repeated at least 3 times at optimal intensity, and muscle responses were recorded. Responses of both extremities were graphed and average values were calculated using 3 action potential curves for statistical comparison using 4-channel polygraph system (BIOPAC MP35; BIOPAC Systems, Inc., Goleta, CA, USA) and computer software (BIOPAC BSL Pro, version 3.7; BIOPAC Systems, Inc., Goleta, CA, USA).

\section{Histological Assessment of Regenerated Nerves}

After electrophysiological measurements were recorded, $5-\mathrm{mm}$ sciatic nerve biopsy samples were taken from distal coaptation line and middle of the graft from all animals. Rats were then euthanized and nerve tissue samples were incubated in Karnovsky fixative $\left(\mathrm{pH} \mathrm{7.4)}\right.$ ) at $4^{\circ} \mathrm{C}$ for 48 hours. After routine electronmicroscopic procedures, tissue samples were embedded in araldite-epon mixture for polymerization, and I-mm semi-thin sections were taken using ultramicrotome (Leica Ultracut R; Leica Microsystems GmbH, Wetzlar, Germany) and were stained with toluidine blue. Sections were placed on a grid and contrasted using uranyl acetate and lead nitrate. Ultrastructures were evaluated using Zeiss Libra 100 EFTEM (Carl Zeiss AG, Oberkochen, Germany) transmission electron microscope and images were digitally photographed. Axon diameter, myelin thickness, myelin lamellae arrange- ment and morphological characteristics of Schwann cells and connective tissue were analyzed. Histomorphometric analyses were performed using ImageTool version 3.0 (University of Texas Health Science Center at San Antonio, San Antonio, TX, USA) software and images were obtained using an Olympus DP 4I digital camera mounted on an Olympus CX-4I (Olympus, Corp., Tokyo, Japan) light microscope. Biopsy samples were imaged at $\times 4, \times 10, \times 20$, and $\times 40$ magnification and digital images were acquired in JPEG format with maximum resolution. Three distinct $5000-\mu \mathrm{m}^{2}$ areas were examined using ImageTool program at a magnification of $\times 40$. Similarly, axon count was determined at 3 separate $5000-\mu m^{2}$ areas on each animal. Subsequently, 10 myelinated axons were analyzed in $5000-\mu \mathrm{m}^{2}$ areas, diameter of myelinated axons and myelin thickness were determined at 3 different locations, and mean and standard error were calculated.

\section{Statistical Analysis}

All statistical analyses were performed using SPSS version I5.0 (IBM Corp., Armonk, NY, USA) statistical analysis program. Nonparametric differences were identified using Kruskal-Wallis and Mann-Whitney $U$ tests and were considered significant when $\mathrm{p}<0.05$.

\section{RESULTS}

All rats remained healthy throughout the study and no automutilation or foot ulceration was observed.

\section{Electrophysiological Assessments}

After ENMG recordings, nerve conduction velocity (latency) values were determined by measuring time between stimuli and response. Peak-to-peak potentials were calculated from amplitude difference between positive and negative peak. Both extremities of all rats were measured at least 3 times and mean latency and peak-to-peak value of right (test group) and left (control group) sides were compared (Table I).

Peak-to-peak and average latency values differed between test and control sides $(p<0.05)$ and indicated that present repair procedure produced superior results.

Moreover, ratio of average latency and peak-to-peak value test (right side) and control (left side) groups [(right/left) $\times 100]$ significantly differed between Groups I and 2 ( $p<0.05$; Fig. 2).

Table I. Electrophysiological analysis

\begin{tabular}{|c|c|c|c|c|c|c|}
\hline & \multicolumn{2}{|c|}{ Group I } & \multicolumn{2}{|c|}{ Group 2} & \multicolumn{2}{|c|}{ Group 3} \\
\hline & Left & Right & Left & Right & Left & Right \\
\hline Latency (ms) & $1.48 \pm 0.02$ & $2.15 \pm 0.09$ & $1.44 \pm 0.05$ & $3.10 \pm 0.27$ & $1.47 \pm 0.09$ & $2.55 \pm 0.09$ \\
\hline Peak to peak (mV) & $4.25 \pm 0.49$ & $2.28 \pm 0.24$ & $4.94 \pm 0.74$ & $1.21 \pm 0.23$ & $4.18 \pm 0.85$ & $1.76 \pm 0.17$ \\
\hline
\end{tabular}




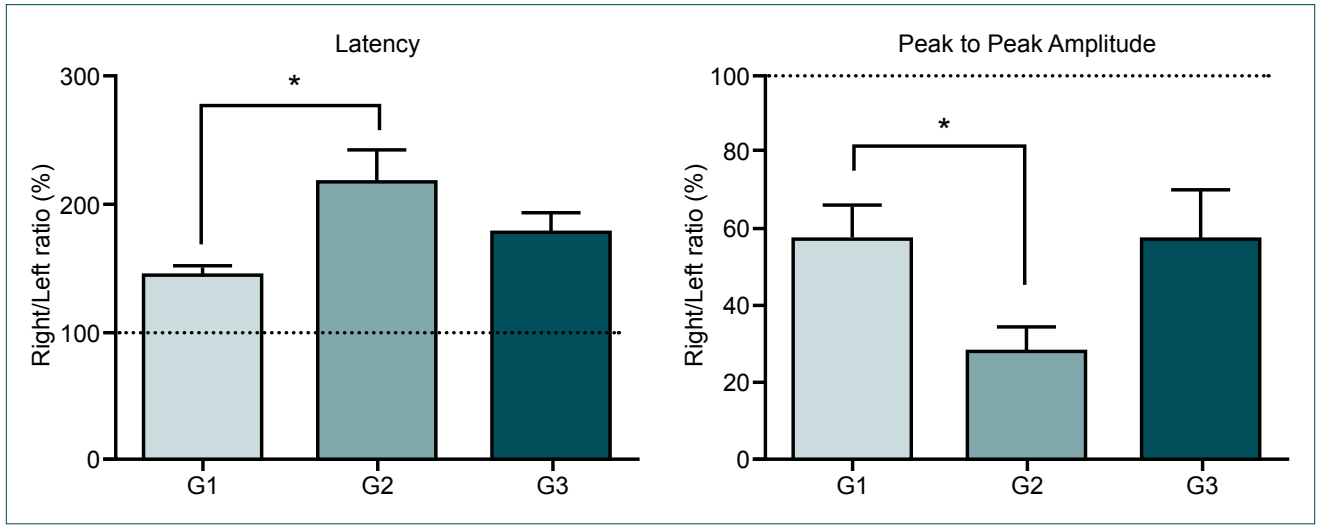

Figure 2. Average latency, peak-to-peak values, and right/left ratios of rats from Groups 1, 2 and 3 .

\section{Histomorphological Assessments}

Group I (nerve graft group): Unmyelinated axons were infrequently observed in sections from grafts and distal parts of grafts. Although nearly normal number and diameter of myelinated axons were observed and were well organized in graft sections, myelinated axons and some degenerated axons were found in distal sections. Similarly, electron microscopy analyses revealed that myelinated axons and myelin sheath of nerve fibers generally maintained normal structure, and Schwann cells were wrapped around myelinated and unmyelinated nerve fibers (Fig. 3a, b).

Group 2 (vein graft group): In sections of mid portions and distal parts of vein grafts, irregular organized myelinated axons and demyelinated axons were observed in some areas, with increased peripheral vascularity. However, small number of myelinated axons was found in sections of distal vein grafts. Moreover, diameter of myelinated axons and myelin thickness was decreased, and fibrosis and increased vascularity were observed in some areas. In addition, electron microscope analyses indicated that myelin sheaths were invaginated toward the inside of axons in significant proportion of myelinated nerve fibers, and local myelin sheath lamellae separation was evident (Fig. 3c, d).

Group 3 (stuffed nerve group): Examination of sections from proximal and distal parts of grafts revealed multiple regularly organized myelinated axons in sections of the graft. Moreover, myelin thickness and axon diameter were sufficient in distal sections of grafts and even greater in some areas. Electron microscope images of Groups I and 3 were similar (Fig. 3e, f).

\section{Histomorphometric Analyses}

Light microscopy images at $\times 40$ magnification were analyzed using ImageTool program, and the number and diameter of axons $(\mu \mathrm{m})$, and myelin sheath thickness $(\mu \mathrm{m})$ were measured in cross sections from distal and middle specimens (Table 2).

Axon count was estimated in 3 different $5000-\mu m^{2}$ central and distal coaptation areas of grafts in animals from treatment Groups I, 2, and 3. Number of axons significantly differed between Groups 1 and 2 and between Groups 2 and 3 ( $p<0.05$; Fig. 4).

In addition, 10 myelinated axons were selected from central areas of graft and distal sections of coaptation areas in all animals using $\times 40$ magnification ImageTool program, selected axon diameter $(\mu \mathrm{m})$ and myelin thickness $(\mu \mathrm{m})$ were measured in 3 different areas for each axon and mean axon diameter was calculated for each treatment group. Mean axon diameter differed significantly between Groups $I$ and 2 and between Groups 2 and 3 ( $p<0.05$; Fig. 5).

Myelin thickness differed significantly between Groups I and 2 and between Groups 2 and 3 ( $p<0.05$; Fig. 6).

\section{DISCUSSION}

Autogenous nerve grafting is currently ideal method for re-

Table 2. Histomorphometric analysis

\begin{tabular}{|c|c|c|c|c|c|c|}
\hline & \multicolumn{2}{|c|}{ Group I } & \multicolumn{2}{|c|}{ Group 2} & \multicolumn{2}{|c|}{ Group 3} \\
\hline & Middle & Distal & Middle & Distal & Middle & Distal \\
\hline Number of axons & $97.4 \pm 6.3$ & $101.6 \pm 6.6$ & $62.1 \pm 4.4$ & $61.6 \pm 4.5$ & $91.8 \pm 3.6$ & $83.5 \pm 5.7$ \\
\hline Diameter of axons $(\mu \mathrm{m})$ & $7.20 \pm 0.7$ & $7.44 \pm 0.4$ & $5.44 \pm 0.1$ & $4.40 \pm 0.3$ & $7.14 \pm 0.2$ & $7.28 \pm 0.5$ \\
\hline Myelin sheath thickness $(\mu \mathrm{m})$ & $1.36 \pm 0.1$ & $1.37 \pm 0.1$ & $0.85 \pm 0.01$ & $0.80 \pm 0.01$ & $\mid .4 I \pm 0.2$ & $1.54 \pm 0.1$ \\
\hline
\end{tabular}



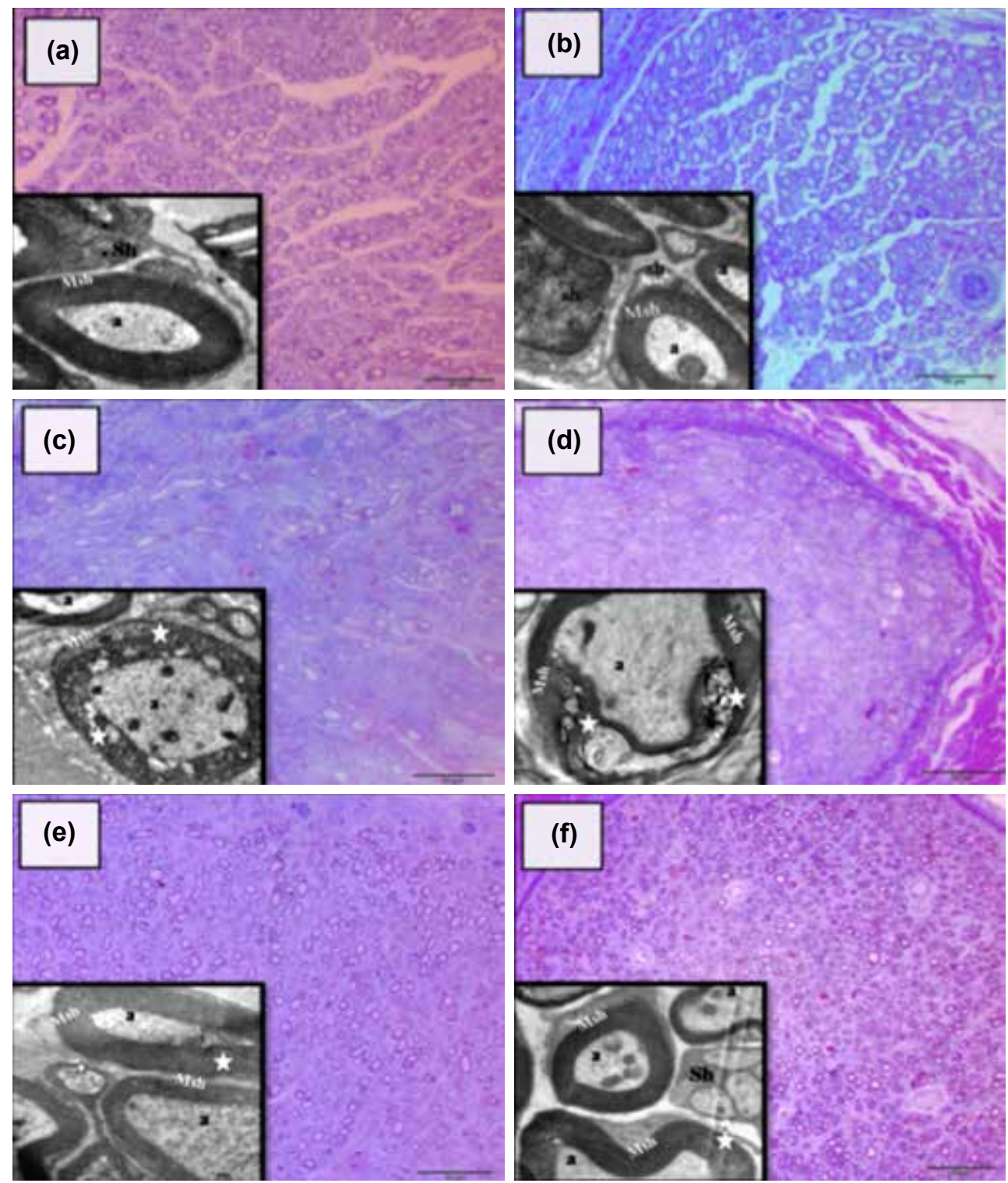

Figure 3. Electron and light microscopy analyses. (a) and (b), Group 1; (c) and (d), Group 2; (e) and (f), Group 3. Sections (a), (c), and (e) were obtained from middle part of the nerve, whereas sections (b), (d), and (f) were obtained from distal part of the nerve. All images are of semi-thin sections stained with toluidine blue ( $\times 40$ magnification) and small frames represent electron microscopic micrographs stained with lead citrate-uranyl acetate; (a-c) and (d), $\times 10000 ;(e)$ and $(\mathbf{f})$ sections, $\times 8000$. Myelinated nerve axons (a), myelin sheath (Msh) and Schwann cells (Sh) were observed. Changes in myelinated nerve fibers are indicated with a star ( $\star$ ). Myelin sheath lamellae degeneration is visible in (c) and (d).

pairing peripheral nerve defects. ${ }^{[20]}$ However, nerve grafting from donor site requires anesthesia and may lead to paresthesia, neuroma formation, pain, and additional scarring. Moreover, long surgery duration and mismatches of diameter may occur. ${ }^{[21]}$ Thus, development of simpler and more functional procedures that reduce morbidity are eagerly awaited. Recent studies have examined various conduits using biological fillings and synthetic tubes to repair nerve defects. In particular, biological and synthetic conduits with similar qualities to autogenous nerve grafts reportedly provide suitable microenvironments for axonal regeneration. ${ }^{[22,23]}$ Vein grafts are the most frequently used biological conduits, and autog- enous vein grafts have been widely used as biological conduits for the regeneration and maturation of nerve fibers in both experimental and clinical settings. ${ }^{[12,24,25]}$ Vein grafts are nonimmunogenic, easier to obtain than nerve grafts, and last longer than bioabsorbable nerve tubes. Moreover, various alternatives are available to accommodate range of diameters, and autogenous tissue grafts do not need to be removed from the surgical field after nerve repair. Furthermore, all 3 layers of vein graft are rich in laminin and share similarities with the basal lamina that surrounds normal and traumatized nerve fibers. Laminin plays role in the adhesion, multiplication, and differentiation of nerve cells. ${ }^{[26]}$ The most commonly ob- 


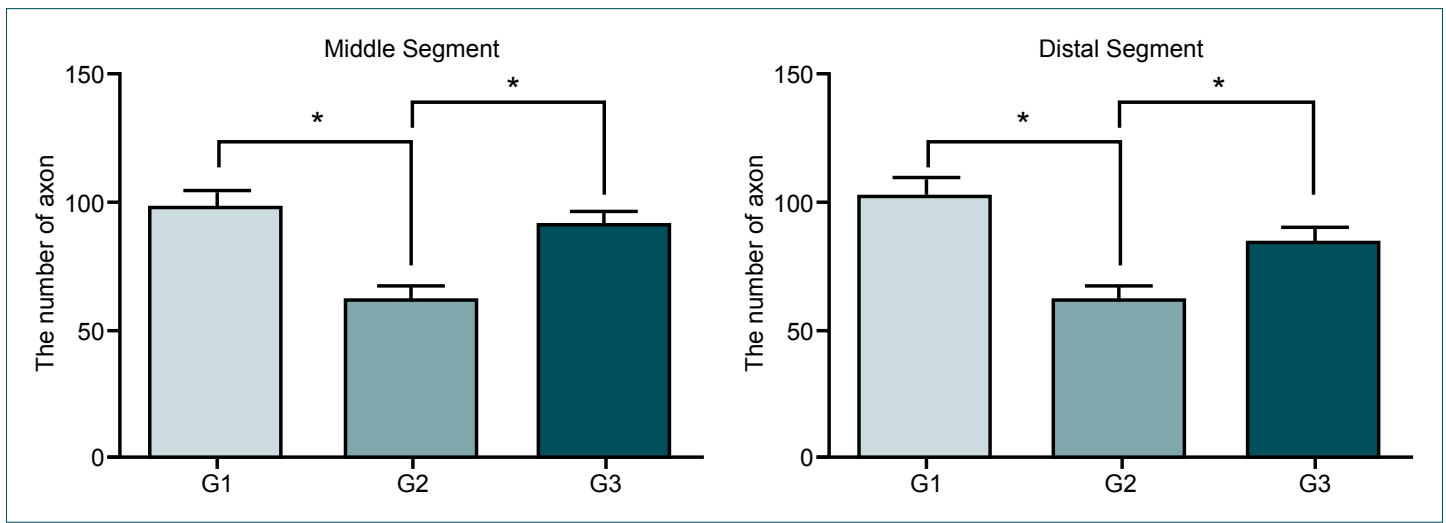

Figure 4. Statistical analyses of axon count in central graft areas and distal coaptation sections of grafts.

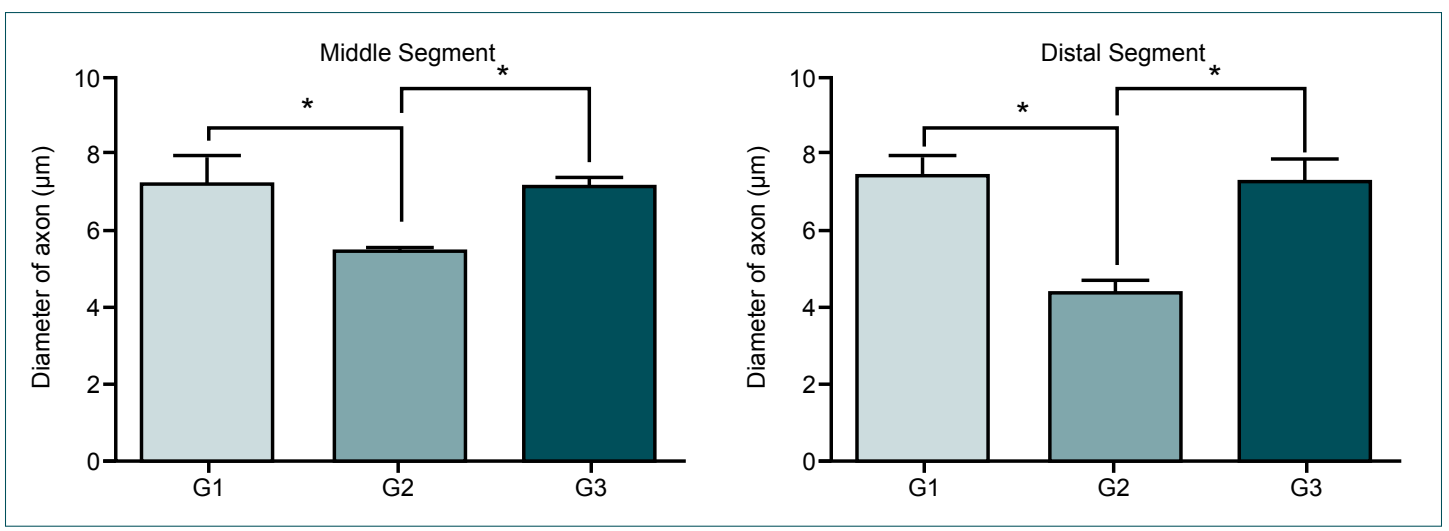

Figure 5. Comparison of axon diameter from central area of graft and distal coaptation area between animals of Groups 1,2 , and 3 .

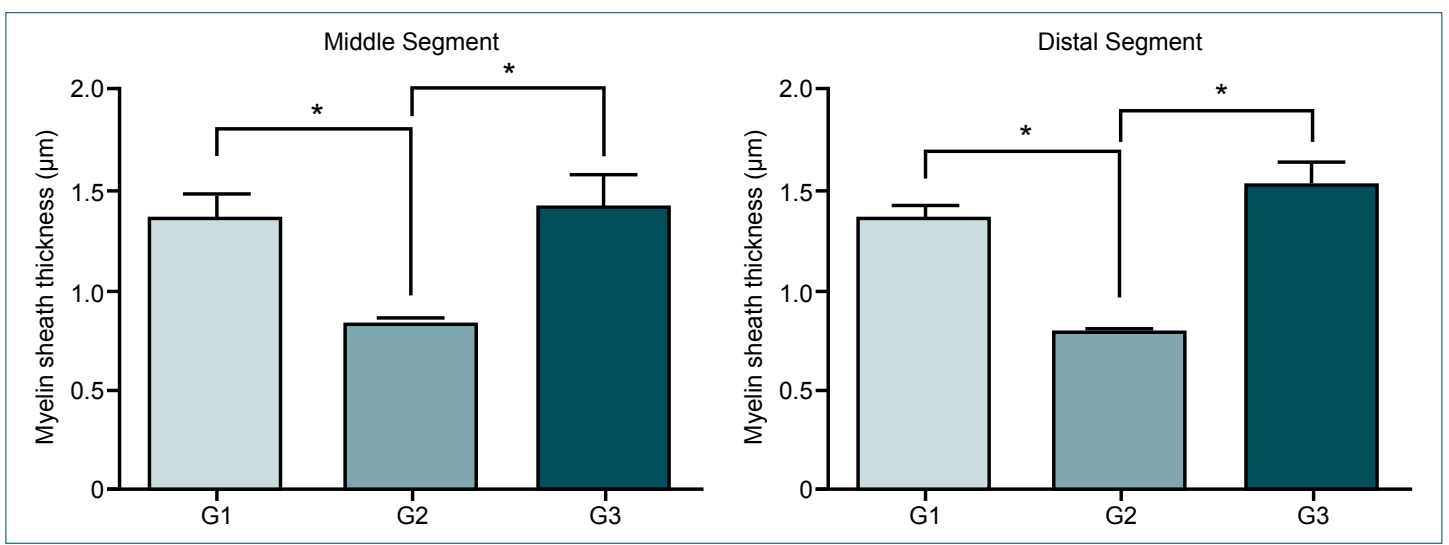

Figure 6. Comparison of mean myelin thickness from central area of graft and distal coaptation area from animals in Groups 1, 2, and 3.

served disadvantage of vein grafts is fibrotic contraction and associated risks of curling and collapse..$^{[4,16,27]}$ Hence, the use of vein graft with other materials that benefit axonal growth will likely produce significant improvements in outcomes.

To reduce complications of vein grafts, Keskin et al. enhanced graft microenvironment by forming biological conduit with nerve graft inside vein graft, and functional, electrophysiological and histomorphometric evaluations revealed no significant differences with nerve grafts. ${ }^{[17]}$ Alternatively, Sahin et al. cre- ated $\mathrm{I}-\mathrm{cm}$ defect on rat's tibial nerve and repaired it with minced nerve tissue in vein graft ${ }^{[23]}$ and then placed $I$ of the 3 equal-sized pieces of nerve graft into vein graft. Although they did not report details of their mincing process, subsequent outcomes were similar to those achieved with autogenous nerve grafts. Similarly, we divided nerve graft into as many small pieces as possible prior to placement in vein graft, which was then tightly stuffed into the defect area (Fig. If). In subsequent analyses, no fibrosis was observed, and axonal regeneration was almost identical to that following autogenous 
nerve grafts. In histomorphometric analyses, Sahin et al. only determined myelinated axon counts, whereas we also determined myelin sheath thickness and axon diameter (Table 2). However, further gait analyses are required to confirm the efficacy of stuffed nerve grafts.

In a previous study, silicon conduits containing minced nerves were placed into 12-mm defects in rat sciatic nerve. ${ }^{[28]} \mathrm{How}$ ever, no significant difference in motor or sensory variables was observed between animals with differing nerve fragments, potentially reflecting use of non-biological synthetic conduit that lacks the selective permeability and flexibility of vein graft. In addition, those investigators did not perform electrophysiological assessments to confirm histological and morphometric observations.

In another study, Zhang created $4-\mathrm{cm}$ defect in rabbit tibial nerve and repaired it with autologous vein graft containing transplanted Schwann cells or with conventional vein graft. Subsequent comparisons revealed superior axon regeneration in veins with transplanted Schwann cells. ${ }^{[2]}$ However, Schwann cells are difficult to isolate and are expensive, making the use of minced nerve parts as shown in the present study a practical option.

Although numerous biological and synthetic nerve conduits continue to be investigated, none have clinical advantages over conventional nerve grafts. However, present vein grafts are biological tubes, and suitable microenvironment was produced by stuffing shredded nerves into the graft, providing neurotrophic and neurotropic factors for axon regeneration. Subsequent ENMG analyses showed shorter latency in nerve graft group (Group I) than in vein graft group (Group 2), suggesting more rapid transmission of growth signals in the presence of nerve tissue. Peak-to-peak potential was significantly higher in nerve graft group than in vein graft group, reflecting more efficient axonal progress. However, latencies and peak-to-peak potentials did not significantly differ between Groups I and 3, indicating similar properties of autogenous and stuffed nerve grafts.

The concept of regeneration unit is that axonal sprouting occurs, involving movement of myelinated axons toward the endoneurial tube. Numerous axons have been observed previously in histological analyses of nerve repair areas, although these axons were not fully functional until they gained access to appropriate receptors. ${ }^{[30]}$ Functional recovery has been observed following the access of sufficient numbers of axons to correct sensory/motor destinations. ${ }^{[3]}$ However, number of axons may be excessive in experimental models, and inappropriate axons that cannot locate appropriate end-organs are removed from fascicles and eliminated by atrophy over some years. In a rat model of nerve repair, distal axon numbers were significantly increased in the first few months and were present in numbers twice normal at 3 months and 2 years. ${ }^{\text {[32] }}$ Axon diameter is dependent on the source and maturity of the nerve, and degree of myelination has been associated with axon maturity. ${ }^{[33]}$ Because myelination occurs before contact of axons with target organs, it may not be associated with function. However, rate of axon myelination may indicate progress of regeneration. ${ }^{[34,35]}$

Accordingly, number and diameter of myelinated axons as well as myelin sheath thickness were determined in the present histomorphological analyses, and there were significant differences between Groups I and 2 and between Groups 2 and 3 $(p<0.05)$. Number, diameter and myelin thickness of axons in Group 2 were smaller than in the other groups, and similarities between Groups I and 3 indicated equivalent regeneration following nerve and stuffed nerve grafts (Figs. 4, 5 and 6).

In summary, the effects of autogenous nerve, conventional vein, and stuffed nerve grafts on axonal regeneration were compared using series of electrophysiological and histomorphological analyses. These experiments demonstrated that autogenous nerve and stuffed nerve grafts were more successful than conventional vein grafts.

\section{Conclusion}

In the present study, repair of sciatic nerve defects using stuffed nerve tissue was superior to conventional vein graft technique. The present technique offers advantages of avoiding collapse often seen in vein grafts to repair defects of $>3$ $\mathrm{cm}$. Defect size and nerve diameter were limited to rat sciatic nerves in the present study, precluding comparisons with previous studies. Nonetheless, the present data indicate that stuffed nerve grafts offer convenient alternative to nerve grafts, which have disadvantage of donor site morbidity. Additional basic and clinical studies of stuffed nerve graft applications are warranted.

Conflict of interest: None declared.

\section{REFERENCES}

1. Chehrazi B. Peripheral nerve injuries: principles of surgical management and outcome. J Neurotrauma 1989;6:191-6. Crossre

2. Chen MB, Zhang F, Lineaweaver WC. Luminal fillers in nerve conduits for peripheral nerve repair. Ann Plast Surg 2006;57:462-71. Crossre]

3. IJkema-Paassen J, Jansen K, Gramsbergen A, Meek MF. Transection of peripheral nerves, bridging strategies and effect evaluation. Biomaterials 2004;25:1583-92. Crossre]

4. Weber RA, Breidenbach WC, Brown RE, Jabaley ME, Mass DP. A randomized prospective study of polyglycolic acid conduits for digital nerve reconstruction in humans. Plast Reconstr Surg 2000;106:1036-45; discussion 1046-8. Crossre

5. Bini TB, Gao S, Xu X, Wang S, Ramakrishna S, Leong KW. Peripheral nerve regeneration by microbraided poly(L-lactide-co-glycolide) biodegradable polymer fibers. J Biomed Mater Res A 2004;68:286-95. Crossre.

6. Sufan W, Suzuki Y, Tanihara M, Ohnishi K, Suzuki K, Endo K, et al. Sciatic nerve regeneration through alginate with tubulation or nontubulation repair in cat. J Neurotrauma 2001;18:329-38.

7. Dellon AL, Mackinnon SE. An alternative to the classical nerve graft for the management of the short nerve gap. Plast Reconstr Surg 
1988;82:849-56. Crossret

8. Inada Y, Morimoto S, Takakura Y, Nakamura T. Regeneration of peripheral nerve gaps with a polyglycolic acid-collagen tube. Neurosurgery 2004;55:640-6; discussion 646-8. Crossret

9. Matsumoto K, Ohnishi K, Kiyotani T, Sekine T, Ueda H, Nakamura T, et al. Peripheral nerve regeneration across an $80-\mathrm{mm}$ gap bridged by a polyglycolic acid (PGA)-collagen tube filled with laminin-coated collagen fibers: a histological and electrophysiological evaluation of regenerated nerves. Brain Res 2000;868:315-28. Crossre]

10. Evans GR. Challenges to nerve regeneration. Semin Surg Oncol 2000;19:312-8. Crossree

11. Yannas IV, Hill BJ. Selection of biomaterials for peripheral nerve regeneration using data from the nerve chamber model. Biomaterials 2004;25:1593-600. Crossret

12. Chiu DT, Janecka I, Krizek TJ, Wolff M, Lovelace RE. Autogenous vein graft as a conduit for nerve regeneration. Surgery 1982;91:226-33.

13. Brushart TM. Nerve repair and grafting. In: Green DP, Hotchkiss RN, Pederson WC, editor. Green's operative hand surgery. Vol. 2. Philadelphia: Churchill Livingstone; 1999. p 1381-403.

14. Chiu DT. Autogenous venous nerve conduits. A review. Hand Clin 1999;15:667-71.

15. Foidart-Dessalle M, Dubuisson A, Lejeune A, Severyns A, Manassis Y, Delree P, et al. Sciatic nerve regeneration through venous or nervous grafts in the rat. Exp Neurol 1997;148:236-46. Crossre

16. Suematsu N, Atsuta Y, Hirayama T. Vein graft for repair of peripheral nerve gap. J Reconstr Microsurg 1988;4:313-8. Crossret

17. Keskin M, Akbaş H, Uysal OA, Canan S, Ayyldz M, Ağar E, et al. Enhancement of nerve regeneration and orientation across a gap with a nerve graft within a vein conduit graft: a functional, stereological, and electrophysiological study. Plast Reconstr Surg 2004;113:1372-9. Crossret

18. Battiston B, Tos P, Cushway TR, Geuna S. Nerve repair by means of vein filled with muscle grafts I. Clinical results. Microsurgery 2000;20:32-6.

19. Battiston B, Tos P, Geuna S, Giacobini-Robecchi MG, Guglielmone R. Nerve repair by means of vein filled with muscle grafts. II. Morphological analysis of regeneration. Microsurgery 2000;20:37-41. Crossre]

20. Ayhan S, Yavuzer R, Latifoğlu O, Atabay K. Use of the turnover epineurial sheath tube for repair of peripheral nerve gaps. J Reconstr Microsurg 2000;16:371-8. Crossree

21. Mackinnon SE. Surgical management of the peripheral nerve gap. Clin
Plast Surg 1989;16:587-603.

22. Terzis JK, Kostas I. Vein grafts used as nerve conduits for obstetrical brachial plexus palsy reconstruction. Plast Reconstr Surg 2007;120:1930-41.

23. Sahin C, Karagoz H, Kulahci Y, Sever C, Akakin D, Kolbasi B, et al. Minced nerve tissue in vein grafts used as conduits in rat tibial nerves. Ann Plast Surg 2014;73:540-6. Crossret

24. Smahel J, Jentsch B. Stimulation of peripheral nerve regeneration by an isolated nerve segment. Ann Plast Surg 1986;16:494-501. Crossret

25. Thanos PK, Okajima S, Terzis JK. Ultrastructure and cellular biology of nerve regeneration. J Reconstr Microsurg 1998;14:423-36. Crossre.

26. Doolabh VB, Hertl MC, Mackinnon SE. The role of conduits in nerve repair: a review. Rev Neurosci 1996;7:47-84. Crossret

27. Whitworth IH, Doré C, Hall S, Green CJ, Terenghi G. Different muscle graft denaturing methods and their use for nerve repair. Br J Plast Surg 1995;48:492-9. Crossre]

28. Lloyd BM, Luginbuhl RD, Brenner MJ, Rocque BG, Tung TH, Myckatyn TM, et al. Use of motor nerve material in peripheral nerve repair with conduits. Microsurgery 2007;27:138-45. Crossre

29. Zhang F, Blain B, Beck J, Zhang J, Chen Z, Chen ZW, et al. Autogenous venous graft with one-stage prepared Schwann cells as a conduit for repair of long segmental nerve defects. J Reconstr Microsurg 2002;18:295300. Crossret

30. Kanaya F, Firrell JC, Breidenbach WC. Sciatic function index, nerve conduction tests, muscle contraction, and axon morphometry as indicators of regeneration. Plast Reconstr Surg 1996;98:1264-74. Crossre.

31. Saray A, Can B, Akbiyik F, Askar I. Ischaemia-reperfusion injury of the peripheral nerve: An experimental study. Microsurgery 1999;19:374-80.

32. Mackinnon SE, Dellon AL, O'Brien JP. Changes in nerve fiber numbers distal to a nerve repair in the rat sciatic nerve model. Muscle Nerve 1991;14:1116-22. Crossre

33. Zenzai K, Shibata M, Okado H, Endo N, Hirano S. Newly-formed axonal branches of rat sciatic neurons sprouting in the spinal cord after peripheral axotomy. Scand J Plast Reconstr Surg Hand Surg 2004;38:129-34.

34. George LT, Myckatyn TM, Jensen JN, Hunter DA, Mackinnon SE. Functional recovery and histomorphometric assessment following tibial nerve injury in the mouse. J Reconstr Microsurg 2003;19:41-8. Crossree

35. Keilhoff G, Fansa H. Successful intramuscular neurotization is dependent on the denervation period. A histomorphological study of the gracilis muscle in rats. Muscle Nerve 2005;31:221-8. Crossrel

\section{DENEYSEL ÇALIŞMA - ÖZET}

\section{Periferik sinir defektlerinin onarımında biyolojik tüp kullanımı 'sinir dolması'}

\section{Dr. Sercan Çapkın, ${ }^{1}$ Dr. Mustafa Akhisaroğlu, ${ }^{2}$ Dr. Bekir Uğur Ergür, ${ }^{3}$ Dr. Ali Abdülkadir Bacakoğlu ${ }^{4}$}

${ }^{1}$ Hınıs Şehit Yavuz Yürekseven Devlet Hastanesi, Ortopedi ve Travmatoloji Kliniği, Erzurum
${ }^{2}$ Dokuz Eylül Üniversitesi Tıp Fakültesi, Fizyoloji Anabilim Dalı, İzmir
${ }^{3}$ Dokuz Eylül Üniversitesi Tıp Fakültesi, Histoloji ve Embriyoloji Anabilim Dalı, İzmir
${ }^{4}$ Dokuz Eylül Üniversitesi Tıp Fakültesi, Ortopedi ve Travmatoloji Anabilim Dalı, İzmir, Türkiye

AMAÇ: Periferik sinir defektlerinin onarımında 'sinir dolması' tekniği araştırıldı.

GEREÇ VE YÖNTEM: Çalışmada 2 I adet Wistar Albino cinsi sıçan kullanıldı. Her grupta yedi sıçan olacak şekilde üç grup belirlendi. Tüm sıçanların siyatik sinirinde 10 mm'lik defekt oluşturuldu. Grup I'de otojen sinir grefti ile, grup 2'de içi boş ven grefti ile, grup 3'de içi parçalanmış sinir ile doldurulmuş ven grefti ile onarım yapıldı. On ikinci haftanın sonunda aksonal rejenerasyonu değerlendirmek için elektrofizyolojik ve histomorfolojik analizler yapıldı.

BULGULAR: Latans süresi ve tepe-tepe potansiyelleri istatistiksel olarak karşılaştırıldığında grup I ve grup 3 , grup 2 ve grup 3 arasındaki fark anlamsızdı. Grup I'in latans süresi grup 2'den daha kısa ve tepe-tepe potansiyeli ise daha büyüktü. Aksonal rejenerasyonu değerlendirmek için; akson sayısı, akson çapı ve miyelin kılıf kalınlığı gruplar arasında karşılaştıııldı. Aksonal rejenerasyonun grup I ve grup 3'de benzer olduğu ayrıca grup 2'den daha iyi olduğu görüldü.

TARTIŞMA: Sinir dolması tekniğinin otojen sinir grefti ile benzer elektrofizyolojik ve histomorfolojik özellikler göstermesi otojen sinir greftinin bir alternatifi olabileceğini gösterdi.

Anahtar sözcükler: Biyolojik tüp; periferik sinir defekti; sinir dolması; ven grefti.

Ulus Travma Acil Cerrahi Derg 2017;23(1):7-14 doi: 10.5505/tjtes.2016.89457 